
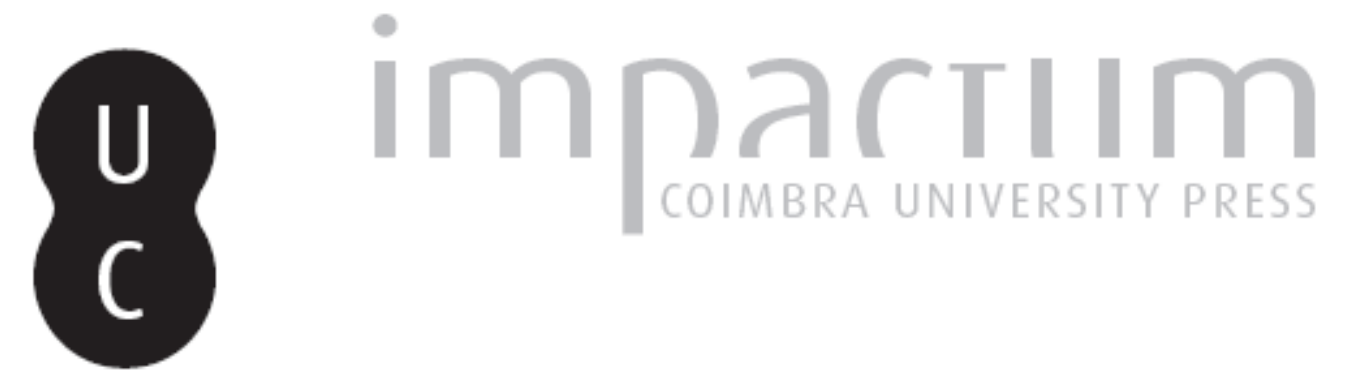

\title{
Hermann Broch: o poeta relutante
}

Autor(es): $\quad$ Cantinho, Maria João

Publicado por: Imprensa da Universidade de Coimbra

URL persistente:

URI:http://hdl.handle.net/10316.2/43727

DOI:

DOI:https://doi.org/10.14195/2183-8925_24_14

Accessed : $\quad$ 26-Apr-2023 16:00:15

A navegação consulta e descarregamento dos títulos inseridos nas Bibliotecas Digitais UC Digitalis, UC Pombalina e UC Impactum, pressupõem a aceitação plena e sem reservas dos Termos e Condições de Uso destas Bibliotecas Digitais, disponíveis em https://digitalis.uc.pt/pt-pt/termos.

Conforme exposto nos referidos Termos e Condições de Uso, o descarregamento de títulos de acesso restrito requer uma licença válida de autorização devendo o utilizador aceder ao(s) documento(s) a partir de um endereço de IP da instituição detentora da supramencionada licença.

Ao utilizador é apenas permitido o descarregamento para uso pessoal, pelo que o emprego do(s) título(s) descarregado(s) para outro fim, designadamente comercial, carece de autorização do respetivo autor ou editor da obra.

Na medida em que todas as obras da UC Digitalis se encontram protegidas pelo Código do Direito de Autor e Direitos Conexos e demais legislação aplicável, toda a cópia, parcial ou total, deste documento, nos casos em que é legalmente admitida, deverá conter ou fazer-se acompanhar por este aviso. 

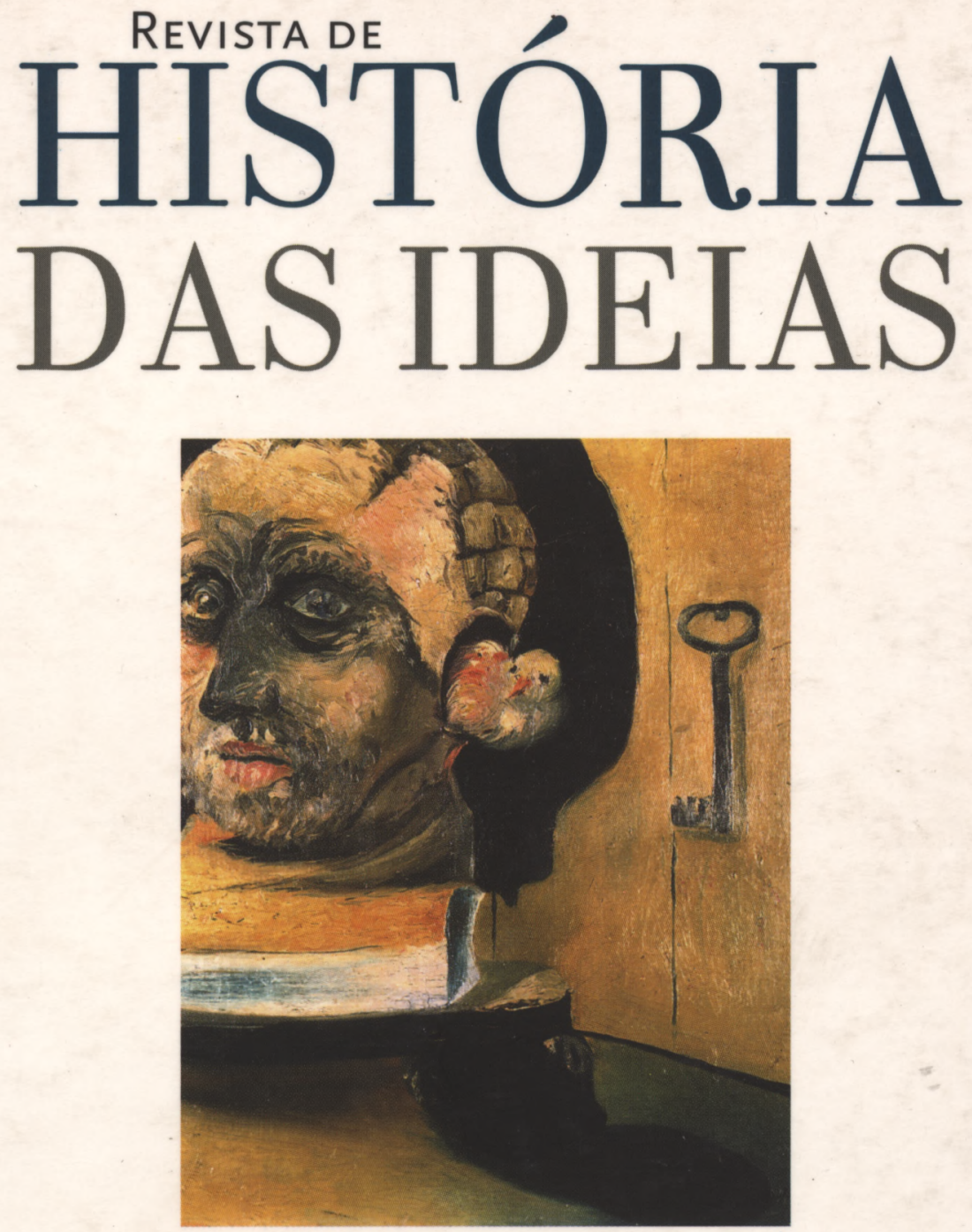

OS INTELECTUAIS E OS PODERES

Volume 24, 2003

INSTITUTO DE HISTÓRIA E TEORIA DAS IDEIAS

Faculdade de Letras da Universidade de Coimbra 


\section{HERMANN BROCH: O POETA RELUTANTE}

"[...] tanto mais poderoso e esquivo se tornava o verbo, um mar pairando, um fogo pairando, pesado como o mar e leve como o mar, mas sempre Verbo: não era capaz de o reter, e não o devia reter; o verbo tornara-se, para ele, inconcebível e inexprimivel, pois estava para lá da linguagem".

Hermann Broch, A Morte de Virgílio, Lisboa, Relógio d'Água, s.d., p. 277

Dele disse Hannah Arendt ter sido um poeta "à sua própria revelia"(1). O facto de ter por destino ser poeta e de não querer sê-lo, transformou-se num dos conflitos centrais da sua vida, inspirando-lhe, ainda, a intriga dramática da sua obra-prima $A$ Morte de Virgílio. Não se tratava de um conflito psicológico ou, mesmo, de uma tensão entre capacidades, pois sabemos como Broch era parente próximo do génio goethiano e que a sua obra assentava sobre a tríade, constituída pelos pólos Literatura, Conhecimento e Acção. Mas a publicação da sua obra literária - no seu conjunto - coincidiu com o aparecimento dos campos de extermínio e o escritor dava primazia absoluta ao domínio da acção sobre os campos da literatura e do conhecimento. Ele jamais poria em causa, fosse qual fosse a situação, o primado absoluto e inviolável da acção. Por isso, obrigou-se a si próprio a interromper a escrita, não por razões meramente

* Doutoranda da Universidade Nova de Lisboa.

(1) Hannah Arendt, Homens em Tempos Sombrios, Lisboa, Relógio d'Água, 1991, p. 131. 
pessoais, mas para cumprir esse imperativo ético com que se deparou. Tornara-se indispensável a sua aç̧ão política, para ajudar as hordas de refugiados que, diariamente, chegavam aos Estados Unidos. Nessa época, nesse confronto entre actividade teorética e contemplativa e a acção política, suspende a sua actividade, enquanto questiona a sua função de artista no século $X X$, aquele que ele considerava o "da mais negra anarquia, do mais negro atavismo, da mais negra crueldade"(2). Todavia, essa tensão constante, entre literatura, conhecimento e acção afectavam-no de um modo permanente, no seu trabalho quotidiano. Disso nos dá testemunho a sua Autobiografia Psíquica, num retrato desenhado com as cores cruas e objectivas da realidade que viveu.

Hermann Broch nasceu em 1886, em Viena, filho de Joseph Broch, grossista em têxteis, saído de uma família judaica e pobre da Morávia, e de Johanna Broch, nascida Schnabel, igualmente judia e filha de um grossista de cabedais, em Viena. Tinha um irmão e as suas lembranças da sua infância são descritas sumariamente em Autobiografia Psíquica como a de uma criança solitária com uma infância desprovida de afecto e impregnada de uma culpabilidade que o haveria de marcar para o resto da vida. A mãe, de temperamento profundamente nevrótico, era uma mulher ríspida para com os filhos, deixando-lhe, além desses traços nevróticos de que fala na sua Autobiografia, uma imagem de mulher-modelo que iria, para sempre, ocupar o centro da sua vida sentimental. O pai, com o seu temperamento rígido e materialista, irritável e violento, anti-intelectual e arrivista por excelência, desprovido de "todo o sentido moral" ${ }^{\prime(3)}$ e totalmente fechado em si, possuía uma certa bonomia, apenas aparente e superficial, que lhe conferia um charme inegável. Em Viena, Joseph Broch era conhecido por "tio Pepi" e frequentava assiduamente bordéis masculinos. A mulher, Johana, fechava os olhos aos hábitos do marido, mas o seu temperamento ia-se agravando, ao longo dos anos, e pioravam também as suas doenças psicosomáticas.

Para ele e à boa maneira burguesa (que Broch tanto detestou e criticou), os pais haviam pensado num futuro de industrial e, de facto, Broch prossegue os seus estudos em engenharia têxtil, mas inscreve-se simulta-

(2) Hermann Broch, Création Littéraire et Conaissance, "Hofmansthal et son temps", Paris, Gallimard, 1955.

(3) O seu neto H. F. Broch von Rothermann, in "Hermann Broch, mon pére", revue Europe, traça dele um retrato nada favorável. 
neamente na Universidade de Viena, onde segue igualmente os cursos de filosofia, de matemática e de física, nos anos de 1904 e 1905. Por volta de 1909, tendo já terminado o curso e estando a trabalhar como assistente da direcção de uma fábrica de têxteis, interrompe e empreende, como voluntário e durante um ano, a sua preparação militar, porém, é obrigado a sair por razões de saúde. Em Julho desse mesmo ano, converte-se ao catolicismo e no Outono desse ano, ainda, torna-se membro do conselho de administração da fábrica familiar, desposando Franziska von Rothermann, filha de um fabricante de açúcar.

Todos os seus actos de revolta e de libertação-lembrando, ainda, a sua (igualmente trágica) proximidade com a culpabilidade de Kafka, a esse propósito - a rejeição da fé paternal, conversão religiosa, casamento, actividades literárias, foram sempre acompanhados de um profundo sentimento de má consciência: por mais que se rebelasse e afastasse, Broch sentia-se sempre culpado, procurando expiar a sua culpa. Desde 1909, procura expurgar a sua revolta, legitimando-a na substituição do que ele considerava as "ociosidades" por escritos teóricos e fragmentários sobre a cultura da época. E essa presença fantasmática e pairante da ética haveria de persegui-lo, durante toda a sua vida, como a sua própria sombra. $\mathrm{O}$ esquema psíquico (que ele reconhece, ao fim e ao cabo de anos de psicanálise), permaneceria mais ou menos imutável, ao longo de toda a sua vida e obra: revolta - esforço de fuga - culpabilidade fracasso no esforço - expiação. E esse "esquema", sabemo-lo por aquilo que Broch nos confessou na sua Autobiografia, era tão apertado que, sem a psicanálise, Broch jamais seria capaz de ultrapassar a culpabilidade asfixiante com que se debatia e escrever. Escrever manteve-o vivo, insuflando-lhe nas veias a vida que nunca soube ter.

Embora seja já um lugar-comum dizer que o autor começou a publicar tarde, é, no entanto, de 1908/1909 que datam os seus primeiros escritos. Em 1910, Broch dedica ao famoso arquitecto Adolf Loos um estudo e diversas sugestões para uma Estética sistemática. Estes escritos de juventude não serão publicados senão após a sua morte, na edição crítica da sua obra completa. É apenas em 1913, na revista Der Brenner de Insbruck e sob a direcção de Ludwig von Ficker, que Broch publicará os seus primeiros escritos. De 1914 a 1917, já como director da fábrica e dirigindo, ainda, um hospital da Cruz Vermelha, continua a publicar diversas críticas de livros, escreve uma série de sonetos, colaborando na revista alemã Die Aktion, de cariz pacifista, e começa a frequentar os meios 
literários de Viena. A amizade une-o a Franz Blei, que dirige a revista Summa, com a qual ele colabora, a Gina Kaus e Robert Musil. A partir de 1918, as suas amizades incluiram Milena Jesenka (a famosa amiga de Kafka), Edit Renyi e Ea von Allesch (com quem viverá, posteriormente, uma relação durante quase dez anos). Continua a sua colaboração com Die Aktion e Summa e de 1919 a 1921, conhece Georg Luckacs, Karl Mannheim, Bela Balasz, escrevendo para revistas prestigiadas como Die Moderne Welt, Der Friede, Der Neue Tag, Die Neue Rundschau, Die Rettung e Prager Presse, entre outras. Enquanto isso, estuda matemáticas, sob a direcção de Ludwig Hofmann.

Em 1922, Broch publica em Prager Presse e em Kantstudien recensões e críticas de livros consagradas à revolução na dialéctica hegeliana e ao pensamento de Marx e Engels. Passados alguns meses, em Abril de 1923, divorcia-se de Franziska e dedica-se, cada vez mais, às suas responsabilidades de industrial. Porém, durante os anos de 1925 e 1926, Broch empreende estudos de filosofia (o positivismo lógico do Círculo de Viena), de matemáticas e de física na Universidade de Viena, sob a direcção dos reputadíssimos Moritz Schlick, Rudolf Carnap, Wirtinger e Hans Hahn. A amizade desse tempo liga-o a Karl Bühler e frequenta os brilhantes e intelectuais salões vienenses de Genia Schwarzwald, Bertha Zuckerkandl e Alma Mahler-Werfel.

É nesta altura que Hermann Broch sente a necessidade de se voltar para a literatura e para a possibilidade de exprimir ideias com que a filosofia não pode ocupar-se de plena legitimidade. Jamais encontramos nele um escritor unicamente preocupado em questões ou pulsões de ordem estética. Quase sempre os seus romances escondem a "pretensão epistemológica", expressão que ele próprio encontra para designar as suas obras. No entanto, ela não pode induzir-nos em erro. Broch não é um ensaísta ou um filósofo dissimulado, que "fala" através dos seus personagens, mas um escritor nato e a sua escrita, patenteando a mais intensa atenção ao pormenor e ao desenho das suas figuras, fá-las encarnar as suas ideias. O modo como o consegue é original, pois permite que desapareça essa estabilidade inquebrantável a que o realismo literário nos habituou, rompendo com as regras previamente estabelecidas e os cânones do romance ${ }^{(4)}$, tão ao gosto burguês da época. Ele nunca

(4) Nos seus ensaios literários, a crítica ao romance, na tradição em que ele se insere, encontra-se sempre subjacente. Daí que ele tenha sido dos primeiros 
descreve directamente a realidade externa ou interna, mas o fluxo da consciência de cada uma das personagens, de tal maneira que o mundo e a realidade aparecem como um conjunto de objectos intencional, numa relação com cada figura que, aí, se desenha. É a partir dessa relação intencional que se desenha o campo subjectivo e emocional de cada uma das suas personagens, numa constante procura de uma experiência, apesar de subjectivamente determinada, construída como um continuum temporal que define a coerência da sua concepção do mundo.

Por outro lado, mesmo quando Broch é atraído pela tentação de contar histórias, jamais perde a pujança criadora que o caracteriza e que pouquíssimos escritores contemporâneos conseguirão igualar. $O$ romance - na concepção que defende - tem, para ele, essa capacidade de apreender o umbral da irracionalidade, aquilo com que a ciência já não pode ocuparse, como se pode ler no "prospectus metodológico" do primeiro livro, em que escreve ao seu editor: "[...] ele [o romance] abraça todo o domínio da experiência irracional, em particular da zona-fronteira em que o irracional se manifesta como acto, tornando-se assim exprimível ou representável". Mediador eŗ̧tre a ordem do representável, apresentação concreta do irrepresentável - e, no seu caso, do irracional -, o romance consubstancializa esse trilho que permite o acesso ao umbral sagrado da linguagem, no que ela contém de fundante. É disso que Broch nos fala, ao reclamar para a poesia um estatuto de mythos que jamais poderá ser encontrado em qualquer outro domínio do conhecimento humano.

Em 1927, Broch decide vender a fábrica de Teesdorf e inicia psicanálise com Hedwig Schaxel, conhecendo, por esta altura, Anna Herzog. No ano seguinte e durante os dois anos que se seguirão, empreende a criação do seu romance Os Sonâmbulos, começando pelo volume intitulado Huguenau, que será, de facto, o último da trilogia. Durante essa época, escreve e publica também alguns artigos de carácter estritamente filosófico. Hannah Arendt sublinha que a maior virtude desta obra se encontra no facto de ela representar, de um modo singular, a crise do

críticos europeus a compreender James Joyce, numa época em que ele era tão incompreendido e mal aceite pelos críticos literários dessa época. Essa ressalva pode, ainda, ser feita relativamente a Kafka, de cuja atmosfera tantas vezes ele se aproximou. 
romance enquanto forma artística ${ }^{(5)}$. Ao longo dos três volumes que a constituem, compreende uma diversidade de registos que conformam o próprio ritmo do seu pensamento, indo de um lirismo acentuado à mais pura abstracção do ensaio. O sopro que a percorre define exemplarmente a natureza do escritor, na sua busca obsessiva de totalidade e de simultaneidade. Enquanto trilogia, pode-se distinguir a obra em três momentos particulares e três datas correspondentes: 1888 e a dissolução romântica do mundo antigo, 1903 e a confusão anárquica anterior à guerra, 1918 e o nilismo tornado activo na história. O desenvolvimento e articulação entre esses três momentos decisivos deixa bem à vista as características, não puramente descritivas e factuais, que assinalam a desagregação dos valores.

Como o próprio nome do romance o indica, Os Sonâmbulos são indivíduos que existem num estado de epoché entre dois sistemas ou dois ciclos de realidade, do mesmo modo que o sonâmbulo vive entre $o$ sono e a realidade, participando dessas duas ordens. Os sonâmbulos de Broch procuram, a todo o momento, libertar-se dos códigos éticos do passado, em que já não acreditam, mas mergulhados, ainda, num mundo de que fazem parte. Protagonizam situações-limite, nas quais a intrusão do elemento irracional se torna permanente e irrompe, sob a sua forma pulsional. Imersos nos seus ideais, são personagens que inscrevem/ /escrevem no seu próprio corpo o sentido da sua busca e o seu destino, configurando-se como personagens trágicas por excelência.

Quase sempre este jogo entre realidade e onírico está presente, aproximando Broch do universo kafkiano. Na verdade, toda a filosofia contemporânea lhe parece pecar por insuficiência, negligenciando a vastidão dos "territórios" humanos: a metafísica, o irracional, o ético. Daí que o modo mais adequado que Broch parece ter encontrado para reflectir sobre esses domínios seja a ficção e só a escrita criativa lhe permita ampliar e distender o conhecimento e, mesmo, ousar abarcá-lo. Como toda a observação é "dinamitada" pelo relativismo, Broch defendeu a ideia (que sempre o fascinou) de que, para apresentar uma ideia, era necessário igualmente apresentar a personalidade daquele que a pensava. Deste modo, o sujeito da observação devia ser projectado no campo da observação, enquanto "objecto de observação".

(5) Europe, "Hermann Broch e o Romance Moderno". 
Em 1930 Broch assina um contrato de publicação dos Sonâmbulos com Daniel Brody, o director da Rhein Verlag de Munique e Zurique. O primeiro volume, Pasenow ou o Romantismo: 1888 é publicado em 1930, o segundo volume, Esch ou a Anarquia: 1905, em 1931. Em 1932, os primeiros volumes da trilogia serão aclamados pela crítica, mas estão longe de ser um sucesso de venda. Em Abril, dá uma conferência intitulada "James Joyce e a actualidade", que viria a ser incluída na sua obra Criação Literária e Conhecimento. Neste ensaio, a literatura ainda é concebida como "tarefa mítica e acção mítica", enquanto que no estudo sobre Hofsmanthal, escrito doze anos mais tarde, até mesmo a inigualável obra de Dante dificilmente será considerada como mítica. $O$ ensaio sobre Joyce, escrito no mesmo estado de espírito que irrompe nos ritmos líricos e musicais de $A$ Morte de Virgilio, termina com a esperança de um "novo mythos", um mundo que se "ordenasse de novo" e viesse coroar o ímpeto literário de uma determinada época.

Ainda nesse mesmo ano de 1932, será publicado o terceiro volume dos Sonâmbulos, intitulado Huguenau ou a Objectividade: 1918. Entretanto, redige ainda vários artigos críticos para a Die Literarische Welt. A sua peça de teatro, Die Entsühnung, é finalmente representada em Zurique (em 1934) e durante esse tempo Broch continua a escrever artigos de crítica literária para as mais diversas publicações, facto que o coloca na primeira linha da vanguarda dos escritores de língua alemã. É nesta época, ainda livre dos sobressaltos da guerra, que Broch concentrará a sua atenção no desenvolvimento da sua teoria dos valores.

\section{A teoria dos valores e a crítica ao kitsh}

Broch sofreu na pele a devastadora sonda nietszchiana, relativamente à teoria dos valores e podemos sabê-lo hoje, à luz dos seus ensaios e escritos dessa época. Ele tinha plena consciência dessa dívida, relativamente a Nietszche, e a desintegração ou dissolução dos valores era, para ele, a consequência da secularização do Ocidente. Em todo esse processo havia-se dissipado a fé em Deus e havia, igualmente, ruído a concepção platónica do mundo, postulando um "valor" supremo, absoluto e não terreno, o qual conferia a todas as acções humanas um "valor" relativo e que se inscrevia numa hierarquia de valores. De acordo com esta visão empobrecida (Broch situa o início do declínio no final da Idade Média), 
cada um dos fragmentos que subsistiam da visão do mundo religiosa e platónica tinha, agora, a pretensão de se transformar em absoluto, situação que é responsável pela anarquia dos valores. O relativismo dos valores cria uma confusão tal que o homem desespera de aí encontrar o seu próprio lugar, bem assim como as suas referências axiológicas. Um exemplo desse relativismo, podemos encontrá-lo na idolatria da beleza e no crime perpetrado por Nero, ao incendiar Roma. Daí que, na nossa época, o kitsh se converta na maior ameaça à arte, pelo que contém de insidiosamente sedutor e, simultaneamente, de vazio. Ele escapa ao sistema de valores que o controla e reifica-se, por isso, como "o mal no sistema de valores da arte"(6), pela sua deificação descontrolada. A questão torna-se mais clara se entendermos claramente que o mal radical se personifica, aos olhos de Broch, na figura do literato estetizante (categoria na qual incluía Nero, tal como o próprio Hitler). E a afirmação do mal na arte ocorre pelo poder de sedução que o kitsh exerce, força demoníaca e que é, antes de mais, um fenómeno estético e atractivo, tomado no seu sentido mais amplo, pois esses "estetas" sacrificam tudo em nome de uma suposta harmonia e coerência, que se esforça por esconder o vazio dos valores em que assenta (todo o nazismo se converte no mais acabado exemplo do mal, dissimulado sobre a forma da beleza). Seria inevitável que Broch visse no nazismo a figura do mal radical, tal como ele se perfilou no magistral Fausto de Mann ou nos romances de Hermann Hesse. Mas a questão que importa a Broch não é a estéril lamentação da morte e da guerra, da violência, o que, sem dúvida, dissolveria os seus esforços no mais banal dos clichés.

O que nos assombra, de facto, é essa pergunta com que ele nos afronta e na qual remexerá ao longo de toda a sua vida: "Como é que o conhecimento poderia abolir a morte?". A outra, imediatamente decorrente da primeira, como uma espécie de desdobramento, e que supõe um antiquíssimo problema filosófico, é: "Como poderia um homem vir a conhecer tudo?". Tais questões, como as que lhe são adjacentes, arrastam-nos ao coração da sua teoria de conhecimento. Num exercício de clara dedução, a colocação da questão da possibilidade do conhecimento, no caso de Broch, não poderia senão reenviar-nos à reflexão sobre o tempo

(6) Herman Broch, Création Littéraire et Connaissance, "Le mal dans le sistème des valeurs de l'art", Paris, Ed. Gallimard, 1955. 
e a morte, centrais na sua obra, como as questões da totalidade e do absoluto, pois apenas o conhecimento, na perspectiva de Broch, permite abolir a finitude. Dessa forma de conhecimento que tudo deseja e abraça, resulta necessariamente a simultaneidade, abolindo a sucessão do tempo e, por conseguinte, da morte. Instaura-se, assim, na vida humana uma imagem de eternidade, imagem pairante e que confere um novo sentido ao vazio da vida, que era medida pelo tempo-sucessão. Trata-se de conseguir uma simultaneidade que transforme e opere sobre o tempo enquanto sucessão, transmutando-o em coexistência, onde o curso temporalmente estruturado do mundo e do seu fluxo empírico se apresente como imagem de totalidade, que fosse vista por um deus capaz de ver e tudo e tudo dar a ver, na sua simultaneidade.

A ideia de um absoluto que gera, a partir de si, uma "imaginidade em si"; capaz de existir mesmo sem a presença de Deus, constitui um pressuposto equívoco e de natureza duvidosa, se analisado do ponto de vista epistemológico; é reforçado pela sua afirmação de um "absoluto terreno", de costas voltadas para Deus. O facto de tais evidências (não menos imperiosas) só poderem ser expressas em proposições tautológicas não é, para Broch, motivo de descrédito. Se bem que elas possam não ser formalmente válidas, não perdem, no entanto, a sua validade cognitiva.

Broch sempre teve uma consciência aguda da distinção entre este ponto de vista e a filosofia propriamente dita e, por isso, atribui à arte um poder de conhecimento superior ao da filosofia, pela sua capacidade de captar evidências e de possibilitar a abertura do homem à totalidade e ao devir, algo em que a filosofia revela, desde logo, a sua insuficiência. A objecção inicial à filosofia persiste sempre, pois ela não pode oferecer-lhe, dentro da sua lógica de cognição, quaisquer resultados definitivos, face às questões que Broch lhe coloca - a vitória sobre a mortalidade do eu, sobre a contingência e a anarquia dos valores, etc. Ela [filosofia] limita-se a colocar as perguntas a que, outrora, o mythos respondeu através da religião e da poesia. Daí que o misticismo se lhe apresente de modo incontornável na sua vida e na obra. E esse misticismo, que corresponde à exigência da totalidade do conhecimento, à superação da finitude e da morte, contaminará e irradiará como o mais potente caudal do lirismo poético que percorre a sua escrita.

No estudo sobre Hofsmanthal, que será redigido mais tarde e no qual todas essas questões serão mais verticalmente reflectidas e Broch afirmará que ele aprendera com Goethe que "a poesia, para levar à purificação $e$ 
à auto-identificação do homem, tem de mergulhar nas profundezas das antinomias humanas, ao contrário da filosofia, que se deixa ficar à beira do abismo e, sem arriscar o salto, se contenta com a mera análise do que viu". E não era só para a filosofia que Broch guardava esse lugar de serventia, relativamente à literatura, quanto à validade e ao conteúdo do conhecimento, mas também para a ciência. Nessa época, Broch ainda podia afirmar que "o sistema cognitivo da ciência nunca atinge [ao contrário da arte] esse carácter absoluto da totalidade do mundo que, afinal, é a única coisa que importa", enquanto "cada obra de arte é, por si só, o espelho de uma totalidade". Mais tarde, como se verá, essa concepção mudará radicalmente.

Em 1936, Hermann Broch instala-se em Mösern, no Tirol, para se consagrar inteiramente ao seu novo romance, $O$ Sortilégio, enquanto traduz poemas de James Joyce e de T. S. Eliot para a língua alemã, publicando, ainda, uma nova versão do seu ensaio sobre Joyce, bem como um ensaio sobre Robert Musil. Essa obra será retomada no final da sua vida e permanecerá fragmentária. Finalmente, em 1937 Broch redige a primeira versão de $A$ Morte de Virgílio, enquanto trabalha, ao mesmo tempo, na redacção de uma Declaração da Sociedade das Nações, condenando o fascismo e colabora com Hans Vlasics na redacção de uma série de máximas de carácter proverbial. Em 1938, trabalha já numa terceira versão da Morte de Virgílio, quando os nazis o vêm prender a 13 de Maio. Feito prisioneiro, ele continua a trabalhar no romance e é graças à intervenção de James Joyce e do romancista inglês Stephen Hudson, amigo e tradutor de Proust, que Broch obtém, no mês de Julho, um visto para Inglaterra e chega a Londres a 24 de Julho desse ano. Thomas Mann e Albert Einstein obtêm-lhe um visto para os Estados Unidos e ele chega a New York a 9 de Outubro.

Em 1939 e a partir do mês de Abril, Broch vive com amigos no Connecticut, depois numa colónia de artistas, onde continua a trabalhar na Morte de Virgilio e encontra Jean Starr Untermeyer, que se torna a sua tradutora. Colabora, também, com o príncipe Hubertus zu Loewenstein na organização duma ajuda aos refugiados vindos da Alemanha e dos países de língua alemã, invadidos por Hitler.

A Fundação Guggenheim é sensível à sua condição de expatriado e concede-lhe uma bolsa de um ano, em 1940. A quarta versão da Morte de Virgilio é terminada e, em colaboração com o escritor italiano antifascista Giuseppe-Antonio Borgese, começa a redigir uma Declaração em favor de 
uma Democracia Mundial, a qual será publicada em 1941 e Broch ocupa-se, também, com Viktor Polzer, em obter visas de imigração para os refugiados vindos de França. Vive, então, em New York e em Cleveland Heights, no Estado de Ohio. Renovará, nessa época, as suas relações com Anne-Marie Maier-Graefe, que se tornará, mais tarde, a sua segunda esposa e empreende uma primeira versão da sua teoria sobre a psicologia das manifestações colectivas de loucura.

Enquanto que a composição dos Sonâmbulos tinha sido feita por acréscimos sucessivos, numa elaboração arquitectónica, $A$ Morte de Virgilio cresceu organicamente, por enriquecimento e desenvolvimento interno, à maneira de uma "ideia originária" que fosse encontrando a sua consubstancialização, nas suas formas particulares. Broch não designava esta obra como romance, mas antes como um poema lírico que se estende, com o seu fôlego admirável, ao longo de quinhentas páginas. A base de sustentação para o designar como um romance só poderia vir da tradição schlegeliana, para quem o romance seria entendido como tal unicamente num sentido lato, abraçando em si todas as formas poéticas. Construído como um poema sinfónico, na sua estrutura quaternária, todo o poema obedece à organicidade de cada um dos seus andamentos musicais internos. Cada uma das quatro seç̧ões tem um símbolo/ /elemento central (a água, o fogo, a terra e o éter), tal como um modo fundamental, concebido em termos musicais (andante, adagio, maestoso). A sua repetição e desenvolvimento são tratados conscientemente como variações musicais em torno da ideia da morte do poeta.

No contexto deste "quadro sinfónico" que são as últimas dezoito horas da vida de Virgílio, o livro desenvolve-se de acordo com um ritmo distinto. $\mathrm{Na}$ "Chegada", Virgílio toma consciência disperso da sua vida e entra em choque. Todo o ritmo é descrito de modo febril, expondo as mais diversas polaridades e contrastes. À medida que as memórias vão conquistando uma certa unidade e as suas impressões se unem à memória, nesse estado febril ("A Descida"), ele dá-se conta, com terror, de que a sua vida inteira, bem como a sua obra, excluíram toda uma parte da sua existência. Aquilo que a primeira parte apresentava, nos seus contrastes visuais, e a segunda numa visão lírica interior - que aparece sob a forma da noite - a terceira parte, "A Expectativa", recapitula as discussões dialécticas entre Virgílio e os amigos. No último capítulo, "Regresso a Casa", todos estes elementos conflituais se resolvem numa visão grandiosa e unitária, enquanto Virgílio morre. 
É sobretudo na última parte que Broch exprime, além do intenso lirismo, a sua visão mística do mundo e da existência. Hannah Arendt sublinha mesmo a presença do panteísmo de Spinoza ${ }^{(7)}$, chamando-nos a atenção para o modo como o particular e o concreto, nessa obra, não se desvelam senão como aspectos de um Todo eterno, que o poeta vai apreendendo na intensidade dos momentos finais da sua vida. À medida que ele se aproxima da morte, não é só a sucessão de factos particulares que se apresenta, como somos, também, arrastados nesse retrocesso vertiginoso que é a uma história da criação: Virgílio sente-se retroceder progressivamente às etapas anteriores do ser: ele percorre inversamente o caminho do Paraíso, descrevendo as etapas da vida animal, vegetal e mineral. Retorna, passando pela separação original da luz e das trevas, para a fonte de todo o ser. E, neste ponto, nas duas últimas páginas do livro, novamente unido a Deus, ele volta-se e, numa visão final, abraça toda a vida e toda a realidade. A partir desta nova posição de reunificação com o todo, vê agora o modelo da completude na vida. Todas as polaridades desapareceram. Na morte, os contrários reconciliaram-se, para dar lugar ao Uno. A presença de Heraclito pode ser aqui entrevista, na aceitação da dor e do sofrimento, de todos os contrários que assolam o homem e o cindem e que, finalmente, se subsumem na distensão do instante-limite. Vida e morte tornam-se uma e mesma coisa, numa conjuração de uma visão mística, apenas igualável às visões extáticas dos místicos como mestre Eckart ou, numa versão moderna aproximada, aos belos Hinos à Noite de Novalis.

A representação da morte e do acto de morrer, desse gesto sagrado da "escuta da morte", é, sem dúvida, mais do que uma mera imagem ou do que um gesto de virtuosismo literário, levado a cabo por Broch. $\mathrm{Na}$ verdade, ele reflecte a mais íntima essência do homem que vive a escrita na carne, a inscrição do envelhecimento no corpo, e a presença da morte que sempre o acompanhou (nas apresentações da história e do destino do povo hebreu), pelo menos desde a segunda metade da sua vida. Por isso, ela (enquanto imagem e gesto) preenche uma função central na sua obra, que é a libertação do espírito para os problemas éticos da sua própria vida [de Broch] e para preparar o pensamento do futuro. A sua fé, em última análise, residia nesse correlato que se

(7) "Hermann Broch et le roman moderne", in Europe, p. 101. 
apresenta na literatura e na linguagem, 0 "absoluto terreno". A ideia de que seria possível encontrá-lo (e demonstrá-lo, igualmente) consubstanciou-se na sua obra $A$ Morte de Virgilio. Colocando a morte na vida e na obra como expressão dessa procura do "absoluto terreno", Broch pretendia anulá-la, no que ela continha de ameaçador, e abrir a via para um sistema ético fundado, não sobre o peso da morte, mas apenas e somente sobre as exigências da vida, seguindo o fôlego quase insustentável do vitalismo de Nietszche.

$\mathrm{Na}$ verdade, nesta obra, ele quis criar a experiência da morte permitindo ao leitor partilhá-la - enquanto extensão da vida, sobretudo, e não como caos ou aniquilação da vida. É de redenção e de salvação da morte, pela aceitação dos contrários que a própria vida implica, que Broch nos fala e sobre a qual escreve, a cada momento. Sem dúvida que sentimos com a maior das intensidades a presença latente das mais admiráveis páginas que o autor de Assim Falava Zaratustra foi capaz de escrever, celebrando o eterno retorno e a dança do sobre-homem, descobrindo o tempo como eternidade pairante, para lá da morte e do caos. E é, sem dúvida, no cântico da vida, ressoando através dos escombros, que escutamos assombrados o ímpeto vital de Virgílio, encontrando nele a potência do gesto redentor. Esta é a verdadeira significação da quarta parte da obra, na qual Virgílio caminha para a morte, passando por uma série de transformações que a mostram como fonte e complemento da vida, isto é, como "outra" forma de vida. Deste modo, a morte constitui um resolução dos opostos, que nos aparecem tão estilhaçados na primeira parte, pois a dor e o sofrimento, a doença são prolongamentos da morte, como se ela nos aparecesse numa extensão da vida num outro reino. Deste ponto de vista, a perspectiva de Broch aparece igualmente eivada de um romantismo que é tão caro a Hesse como a Rilke.

Em 1942, uma bolsa acordada pela Fundação Rockfeller permite-lhe prosseguir os seus estudos sobre as manifestações de loucura colectiva. Broch tem conhecimento de que a sua mãe, a 9 de Dezembro, morre no campo de concentração de Theresienstadt. Data dessa altura o começo da sua colaboração com $A u f b a u$, o semanário nova iorquino de língua alemã.

Em 1943, começa a psicanálise com Paul Federn, continuando a trabalhar na sua teoria da loucura colectiva, e em 1944 - ano em que se torna cidadão americano - o seu editor americano recebe duma fundação uma subvenção para a publicação da Morte de Virgílio. Finalmente, em 1945, é publicada a obra prima de Broch, em língua alemã e tradução 
americana pela Pantheon Books de New York. Bem recebida pela crítica americana, a obra não é, porém, tão aclamada na Europa.

Broch sempre achou que tinha terminado a sua carreira com $A$ Morte de Virgilio. Ele nunca teve um diário que nos permitisse conhecer as suas confissões, relativamente à sua própria obra literária, mas é sempre por interposta pessoa e através dos seus ensaios literários que o deixa transparecer. Assim, quando escreve sobre Kafka, por exemplo, deixa bem clara a ideia de que a força literária do livro $A$ Morte de Virgilio era demasiado intensa para a sua mensagem, obscurecendo-a. Procedendo a uma autoreflexão dissimulada, acrescentava: "ou a poesia consegue avançar até ao mito ou vai até à falência". E Kafka, que tentara "avançar até ao mito e à cosmogonia", luta contra o seu amor à literatura, sentindo a sua insuficiência fundamental de toda e qualquer abordagem estética e artística. Justamente por isso decidiu abandonar o domínio da literatura, pedindo a Brody que a sua obra fosse destruída (tal como Virgílio pediria a destruição da Eneida, nesse redrobramento simbólico do gesto, na Morte de Virgílio), pediu-o para bem do universo cuja nova concepção mítica lhe fora entregue. Aquilo que Broch diz neste ensaio, além de revelador da sua própria posição, mostra a que ponto levava a cabo com um zelo inexcedível a tarefa ética que se havia proposto.

Esses próximos anos: 1947, 1948 e 1949 serão passados entre a publicação de ensaios e problemas de saúde. Em 1948, redige, no hospital de Princeton, um dos seus mais admiráveis ensaios, "Hofmannsthal e o seu tempo" e começa também a desenvolver uma nova teoria epistemológica. Nesse ensaio, escrito tão próximo do final da sua vida, Broch aborda todas as condições que perfizeram a sua própria vida; a sua origem judaica e assimilação, o esplendor e a queda de uma Áustria em declínio, o meio burguês e respeitável que ele tanto detestava e de que fazia parte e esse exclusivismo literário tão próprio de Viena, a que ele chamava a "metrópole do vazio ético". Todas as suas grandes percepções históricas são, aí, tratadas e de modo admirável, sob o olhar de Hofsmanthal.

Em 1949, muda-se para perto de Yale University, onde redige, Os Irresponsáveis. Continua, no entanto, a publicar muitos artigos e ensaios e a partir de 1950, Hermann Broch dá cursos de literatura alemã em Yale University e o PEN Club austríaco propõe a sua candidatura para o prémio Nobel. A Academia alemã de Letras e Ciências de Darmstadt convida-o para membro e é convidado a participar no primeiro congresso, em Berlim, para a liberdade da cultura. 
Em 1951, o último ano da sua vida, Broch volta ao romance que tinha abandonado, $O$ Sortilégio, mas esta nova versão permanecerá fragmentária. Mesmo assim, o livro será posteriormente publicado, a título póstumo, no texto original alemão, em 1976. Entre todos os romances, Édouard Roditi ${ }^{(8)}$ refere ser este romance uma sinfonia ao mesmo tempo pastoral e diabólica, alucinante e que reflecte toda a influência terrífica que o nazismo instilou em Broch. Se bem que o seu carácter alegórico se aproxime da escrita kafkiana, em especial da atmosfera de $O$ Processo e de $O$ Castelo, no entanto, o estilo deliberadamente romântico de Broch demarca-se do realismo mágico de Kafka, muitas vezes, contrastando mesmo com a economia narrativa daquele.

A maior das ironias encontra-se no facto de Broch, apesar de toda a sua vida lutar contra a "literatura", se consagrar precisamente como romancista. A obra de epistemólogo, a sua teoria de valores e a crítica que fez ao sistema ético vigente, a sua filosofia da história, da psicologia de massas e da política, tudo isso foi, ou praticamente ignorado ou não chegou até nós senão através dos seus romances e de forma indirecta. A história do pensamento cometeu, para com a sua figura - Broch nunca foi académico nem trilhou os caminhos convencionais dos teóricos do conhecimento-, uma injustiça. Mas persiste igualmente um risco imenso em considerá-lo como um filósofo sistemático. Se, por um lado, a sua impaciência e avidez de conhecimento o terá levado a abraçar vários domínios do pensamento, por outro, transformou-se numa vítima da sua própria avidez, caindo na cilada da totalidade. Essa impaciência de que padecia impediu-o de desenvolver um verdadeiro sistema, fosse ele qual fosse, e o seu compromisso radical com a vida arrastou-o num desenvolvimento dinâmico das suas teorias, que jamais se deixariam contaminar pelo olhar derradeiro da medusa. Quase sempre, os grandes sistemas petrificaram nessa gelidez e no estatismo formal que foram e constituíram, antes de mais, a sua própria condição de desenvolvimento. Se quisermos aceder ao seu pensamento, teremos de observar a sua vida, ler as suas cartas e ensaios, os seus romances.

Ele tinha consciência de possuir uma missão a cumprir na sua vida e consagrou-se-lhe com um zelo perpassado de um ímpeto quase messiânico. Como já não sentia que a literatura fosse capaz de contribuir para

${ }^{(8)}$ Cf. Édouard Roditi, "Le Roman Alpin de Broch", in Europe, p. 115. 
a realização dessa tarefa, acaba por depositar todas as suas esperanças na política. É sobretudo neste campo e na possibilidade do "auxílio", enquanto imperativo ético que se coloca acima de todas as contingências, que se propõe trabalhar. Para ele, era evidente, antes de mais, a obrigação de interromper tudo, fosse qual fosse o seu trabalho ou ocupação, para prestar auxílio e, por isso, torna-se-lhe igualmente óbvio que teria de prescindir da literatura, pois duvidava que esta alguma vez pudesse satisfazer a sua "obrigação para com o absoluto da cognição". Começou, também, a duvidar se a literatura e a cognição seriam necessárias ao apoio dos necessitados.

Ao invés do que ele próprio acreditava, as suas ideias não eram originais, aproximando-se muito o seu pensamento da análise existencialista de Jaspers e de Camus, mas isso não deve denegrir aos nossos olhos o seu brilho e a admirável obra que nos legou. Seguramente, ele formulou a sua própria síntese, de uma sedução ímpar no tempo. Há uma nobreza na sua teoria sobre a liberdade humana e no modo como define a responsabilidade humana que só é comparável aos escritos de Lèvinas. A ideia da imanência da morte talvez possa ser considerada como o contributo mais original para a experiência da morte. Essa evocação da totalidade e da simultaneidade da vida, tal como nos aparece na Morte de Virgílio, é a maior conquista da sua literatura e apenas poderemos ser justos se colocarmos a sua obra literária, lado a lado com James Joyce ou Marcel Proust, os heróicos e geniais arquitectos da literatura moderna.

\section{Bibliografia}

Broch, Hermann - Autobiographie Psyquique, Paris, ed. L'Arche, 2001.

Broch, Hermann - La Grandeur Inconnue, traduction par Albert Kohn, Paris, Gallimard, 1968.

Broch, Hermann - Création littéraire et conaissance, traduction par Albert Kohn, Paris, Gallimard, 1966.

Arendt, Hannah, Homens em Tempos Sombrios, Lisboa, Relógio d'Água, 1991.

Theodore Ziolkowski, Von Rothermann, Broch, Arendt, Hannah, Roditi, Édouard, Revue Europe, Paris, 69 année, nº 741-742, janvier-février 1991. 